DEGRUYTER DOI: 10.1515/plass-2017-0018

Jarosław Przetakiewicz

Plant Breeding and Acclimatization Institute - National Research Institute Radzików Research Center, Radzików, 05-870 Błonie, Poland; e-mail: j.przetakieiwcz@ihar.edu.pl

\title{
SAMPLING, MAINTENANCE AND PATHOTYPE IDENTIFICATION OF SYNCHYTRIUM ENDOBIOTICUM (SCHILB.) PERC.
}

\begin{abstract}
Plant Breeding and Acclimatization Institute - National Research Institute (IHAR-PIB) is responsible for pathotype identification of Synchytrium endobioticum isolates collecting from Poland. Pathogenicity tests are carried out using the Glynne-Lemmerzahl method, according to EPPO Standard PM 7/28. Pathotypes are defined based on their reaction to a range of well-characterized differential cultivars of potato. Assessment of one isolate of the fungus requires more than 20 differential cultivars. All pathotypes of $S$. endobioticum from Polish reference collection are multiplied and maintained (fresh warts) on tubers of extremely susceptible cultivars continuously. For all references pathotypes and isolates of S. endobioticum, the compost with winter sporangia are prepared for long-term of maintenance.
\end{abstract}

Key words: potato wart agent, differential cultivars, Glynne-Lemmerzahl method, winter sporangia

\section{INTRODUCTION}

Synchytrium endobioticum (Schilb.) Perc. is a fungus which causes potato wart disease. The fungus is an economically important quarantine organism, and infection of the host can lead to unmarketable tubers and complete yield losses (Hampson, 1993). Its long persistence in soil and the severe losses it inflicts to potato crops have prompted its inclusion into the A2 quarantine list (Anon., 1996). The main host of S. endobioticum is cultivated potato, but the fungus is able to infect other species of the genus Solanum (Malec, 1983). Although S. endobioticum originates from Andean zone in South America, thanks to the popularity of the potatoes it is distributed

Communicated by Ewa Zimnoch-Guzowska 
worldwide. From South America, it spread to North America and Europe at the end of the 19th century. Presently, S. endobioticum is reported in 15 European countries (Anon., 2005). The geographical distribution of this pathogen includes all EPPO region (except a few countries), Asia, North and South America as well as Oceania (New Zealand) (Anon., 1996).

S. endobioticum is a soil-borne obligate biotrophic organism which does not produce hyphae. Winter (resting) sporangia are the dormant structures by which the fungus disperses to establish new infections. Thick-walled winter sporangia, can survive for a long time without plant hosts (Steinmöller et al., 2012), even though adverse condition (Hooker, 1981). After 43 years, in favourable conditions, disease may develop even from single spores of $S$. endobioticum (Przetakiewicz, 2015). Because the thickwalled winter sporangia are extremely durable, effective chemical control measures are not available (Obidiegwu et al., 2014).

For the production and release of zoospores from winter sporangia, free water is essential. Upon infection, potatoes develop galls. Successful infections, however, occur only at young sprouts of susceptible potato cultivars (Karling, 1964). After infection, S. endobioticum produces two different kind of sporangia in the galls. Summer sporangia known as sori have a thin cell wall and form haploid zoospores, which are emerging and steady reinfection of the host tissue like sprouts, tubers, eye tubers, stolons and roots (only in tomato) (USDA, 2007). In appropriate conditions after isogamy of haploid zoospores to diploid zygotes, which are able to infect host cells the winter sporangia are formed which are embedded deeper into the host tissue than the sori (present always on the tuber surface).

More than $40 \mathrm{~S}$. endobioticum pathotypes, defined by their virulence on differential potato cultivars, have been reported (Baayen et al., 2006; Çakir et al., 2009; Przetakiewicz, 2015). Five of these, namely pathotypes 1(D1), $2(\mathrm{G} 1), 6(\mathrm{O} 1), 8(\mathrm{~F} 1)$ and $18(\mathrm{~T} 1)$, are the most important in Europe (Anon., 2004; Flath et al., 2014; Obidiegwu et al., 2014). In Poland, different pathotypes of $S$. endobioticum occur mainly in the rainy mountainous areas of Sudetes and Carpathians. They persist mainly in gardens on small potato plots, a not economically significant potato-growing area but very important for quarantine and phytosanitary measures (down the spread of the spores with water after heavy rains). The economic impact of pathogen is not only because of yield losses but also because of loss of international trade markets, long-term quarantines, and regulatory restrictions placed on infested areas and the buffer zones (Przetakiewicz, 2014).

\section{MATERIALS}

1) Vaseline (Pharma cosmetic),

2) Miedzian ${ }^{\circledR}$ Extra $350 \mathrm{SC}$,

3) Distilled water,

4) $\mathrm{CaCl} 2$ (Alchem grupa Sp. Z o.o.),

5) Sterilized river sand, 
6) Tubers of cv. Evora, cv. Spunta (HZPC Holland B.V.) and cv. Irga (Pomorsko- Mazurska Hodowla Ziemniaka Spółka z o.o.) for multiplication of fresh warts,

7) Plastic boxes (PZT PRYMAT Sp.j.),

EQUIPMENT

1) Climatic chambers (POL-EKO-APARATURA Sp.j.),

2) Refrigerators (Liebherr),

3) Stereoscopic microscope (Motic () ,

4) Light microscope (Delta Optical-GSO),

5) Autoclave (De Ville Biotechnology),

6) Analysette 3 Pro (FRITSCH GmbH),

7) Centrifuge (MPW MED. INSTRUMENTS Sp. Pracy),

\section{PROCEDURE}

\section{Sample treatment}

Soil samples (with winter sporangia) or warted plants from infested fields are collected, according to the EPPO standard PM 3/59 (Anon., 1993). After confirmation of the pathogen presence, the samples are transferred to Laboratory of Quarantine Organisms in Radzików.

1) A soil sample of $1 \mathrm{~kg}$ is suspended in 101 volume of tap water for $24 \mathrm{~h}$ and thoroughly stirred by hand, after which the suspension is wet-sieved.

2) The mixture is divided to at least 10 subsamples and successively sieve using Analysette 3 Pro (Fritsch) with standard set of sieves: $500,250,125,71,40$ and $25 \mu \mathrm{m}$.

3) Sediments from 40 and $25 \mu \mathrm{m}$ are collected from all subsamples and filtered through filter papers No3 (Whatman) using glass filter holders (Advantec MFS, Inc.) connected to a suction pump (AGA Labor).

4) The pellet is dried on filter papers using vacuum $(-0.085 \mathrm{MPa})$. Partially moist sediment is transferred to a centrifuge tube $(50 \mathrm{ml})$ and supplemented with saturated $\mathrm{CaCl}_{2}$ up to $50 \mathrm{ml}$ of each tube.

5) After mixing a $50 \mathrm{ml}$ suspension of saturated $\mathrm{CaCl}_{2}$ and about $10 \mathrm{~g}$ of sediment, the mixtures are centrifuged at $800 \mathrm{~g}$ for $15 \mathrm{~min}$.

6) In order to remove $\mathrm{CaCl}_{2}$ the supernatant is filtered through sieve mesh of $25 \mu \mathrm{m}$ pore size with a lot of distilled water.

7) The sediment $\left(\mathrm{CaCl}_{2}\right.$ free $)$ is filtered through filter papers No50 (Whatman) using the same technique as above.

8) The procedure is repeated two or three times until the most impurities are removed. Finally, about $10 \mathrm{ml}$ of soil extract is obtained from $1 \mathrm{~kg}$ of soil samples. 
Viability of winter sporangia is determined by microscopic examination of sporangia in soil extract. According to Pratt (1976), winter sporangia of $S$. endobioticum are viable if they are filled with greyish granular contents, or dead if plasmolysed and with no apparent content. The spores are counted according to manufacturer's instructions using a Fuchs-Rosenthal or Sedgewick-Rafter counting chamber.

For samples of warted tubers or plants of potato, the Glynne-Lemmerzahl method is used directly if fresh warts contain viable summer sporangia (Anon., 2004). If the galls contain winter sporangia, they have to be isolated from warted tissue firstly and used as inoculum using the ring test (Przetakiewicz, 2016).

\section{Bioassays}

Bioassays with susceptible potatoes included modified Potocek's tube tests described as a ring test (Przetakiewicz, 2016).

1) In the test, infested soil is replaced by soil extract mixed with river sand.

2) On the top of each tuber a plastic ring $(2 \mathrm{~cm}$ high and $3 \mathrm{~cm}$ in diameter) is fixed using warm paraffin. Each ring is filled with sterile river sand up to $1.5 \mathrm{~cm}$ depth.

3) Soil extract $(1 \mathrm{ml})$ is pipetted into each of the 10 rings on susceptible potato genotypes e.g. cvs. Deodara, Tomensa, or Evora, which are extremely susceptible to all known pathotypes of $S$. endobioticum, including 1(D1).

4) The inoculated tubers with rings are moistened, and placed in a plastic box at $16-18^{\circ} \mathrm{C}$ in the dark. The sand in the rings is moistened daily with distilled water to maintain sufficient moisture.

5) During incubation, the sprouts are cut down at the upper edge of the rings.

6) After 14 days of incubation, new sprouts are examined under the stereoscopic microscope.

7) If no potato wart disease is observed, the sprouts are cut down.

8) If proliferation of the sprouts is observed (summer sporangia), the tuber with ring is kept in the sand under the same conditions as described above for wart production.

9) After 4-6 weeks the largest warts are multiplied using GlynneLemmerzahl method (Anon., 2004).

\section{Maintenance of $S$. endobioticum}

All pathotypes of $S$. endobioticum from Polish reference collection [1 (D1), 2(G1), 2(Ch1), 3(M1), 6(O1), 8(F1), 18(T1) and 39(P1)] are multiplied and maintained (fresh warts) on tubers of extremely susceptible cultivars on the continuous basis. Every 4 weeks, the galls of all pathotypes are refreshed using the Glynne-Lemmerzahl method described before. Isolates 
of $S$. endobioticum are multiplied in the same way until their final determination.

For all references pathotypes and isolates of $S$. endobioticum, the compost with winter sporangia are prepared. Thick-walled spores are long-lived and can survive for a long time without plant hosts. To prepare compost, the galls have to be maturate (at least 12 weeks old) and contain dozens of winter sporangia. Warts are cut into $1 \mathrm{~cm}$ pieces or slices. The pieces and slices are well mixed with clean river sand ( $3 \mathrm{~kg}$ of sand per $\mathrm{kg}$ of warts) and incubated at a temperature of $18-25^{\circ} \mathrm{C}$. The mixture is mixed occasionally during the first four months. After four months, the mixture is no longer stirred but is slowly air-dried at the same temperature for two further months. After a total of six months, the compost is ready and can be used as inoculum. When stored at $10-18^{\circ} \mathrm{C}$, the compost can be used for $10-30$ years. Before the compost is used, the sporangia density is determined using the EPPO method (Anon., 1999).

\section{Pathotype identification}

Pathotypes of $S$. endobioticum can be differentiated using differential potato cultivars (Table 1). Individual isolates of $S$. endobioticum may be able to overcome specific resistances. It is therefore useful to define pathotypes based on their reaction to a range of well-characterized differential cultivars of potato. Pathogenicity tests are carried out using the GlynneLemmerzahl method, according to EPPO Standard PM 7/28.

Identification of pathotypes by assessment of their virulence to differential potato cultivars is a difficult and time-consuming task. It is recommended to perform at least three independent tests per identification, using 15 tubers per differential cultivar in each test.

Moreover, differential set from EPPO Standard PM 7/28 does not allow to distinguish between Polish and German pathotypes. For example Polish pathotype 2(Ch1) gives the same profile as pathotype 8(F1). Pathotype 3 (M1) is identical to pathotype 6(O1). Differential potato cultivars for pathotype determination of $S$. endobioticum presented in EPPO Standard PM $7 / 28$, are not enough in order to detect new or local pathotypes already described. For these reasons additional cultivars have been added to the Table 1 .

The reaction of differential cultivars is evaluated after four weeks of incubation. All details are described by Przetakiewicz and Plich (2017). Disease symptoms are scored in three types of reaction (described in details in Table 1): positive (Photo 1), intermediate (Photo 2) and negative reaction (Photo 3). 


\begin{tabular}{|c|c|c|c|c|c|c|c|c|}
\hline \multirow{2}{*}{ Cultivar } & \multicolumn{8}{|c|}{ Virulence profiles of $S$. endobioticum pathotypes } \\
\hline & $1(\mathrm{D} 1)$ & $2(\mathrm{G} 1)$ & $6(\mathrm{O} 1)$ & $8(\mathrm{~F} 1)$ & $18(\mathrm{~T} 1)$ & $2(\mathrm{Ch} 1)$ & 3(M1) & $39(\mathrm{P} 1)$ \\
\hline Deodara & + & + & + & + & + & + & + & + \\
\hline Tomensa & + & + & + & + & + & + & + & + \\
\hline Eesterling & + & + & + & + & + & + & + & + \\
\hline Evora & + & + & + & + & + & + & + & + \\
\hline Producent & - & + & + & + & + & + & + & + \\
\hline Combi & - & + & + & + & + & + & + & + \\
\hline Spunta & - & + & + & + & + & + & + & + \\
\hline Saphir & - & + & - & - & - & - & - & - \\
\hline Otolia & - & \pm & - & - & - & - & - & - \\
\hline Delcora & - & - & \pm & + & + & + & - & + \\
\hline Miriam & - & - & - & \pm & + & \pm & - & + \\
\hline Karolin & - & - & - & - & - & - & - & - \\
\hline Ulme & - & - & - & - & - & - & - & - \\
\hline Asche Sämling & + & + & + & + & + & - & + & - \\
\hline Désirée & - & - & \pm & + & + & + & - & + \\
\hline Talent & - & - & - & + & + & + & + & + \\
\hline Gawin & - & - & - & - & - & - & - & - \\
\hline Bałtyk & - & + & \pm & + & \pm & + & + & \pm \\
\hline Giewont & - & - & \pm & + & + & + & + & + \\
\hline Universal & - & + & + & + & + & + & + & + \\
\hline Blanik & - & - & + & + & + & + & + & + \\
\hline Irga & - & + & + & + & + & + & + & + \\
\hline Nicola & - & - & - & - & - & - & - & + \\
\hline
\end{tabular}

Differential potato cultivars for the identification of pathotypes of Synchytrium endobioticum

Table 1

$(+)$ - positive reaction - predominant wart formation. This category includes only extremely susceptible cultivars (Photo 1).

$( \pm)$ - intermediate reaction - proliferation of sprouts is visible, especially on sprouts which were strongly infected by zoospores of the pathogen, but the malformation of shoot is much weaker in comparison to extremely susceptible cultivars (Photo 2). Winter sporangia are present.

(-) - negative reaction - no warts (Photo 3), but this group may include slightly susceptible cultivars because the resting spores could be present despite no visible proliferation of sprouts. 

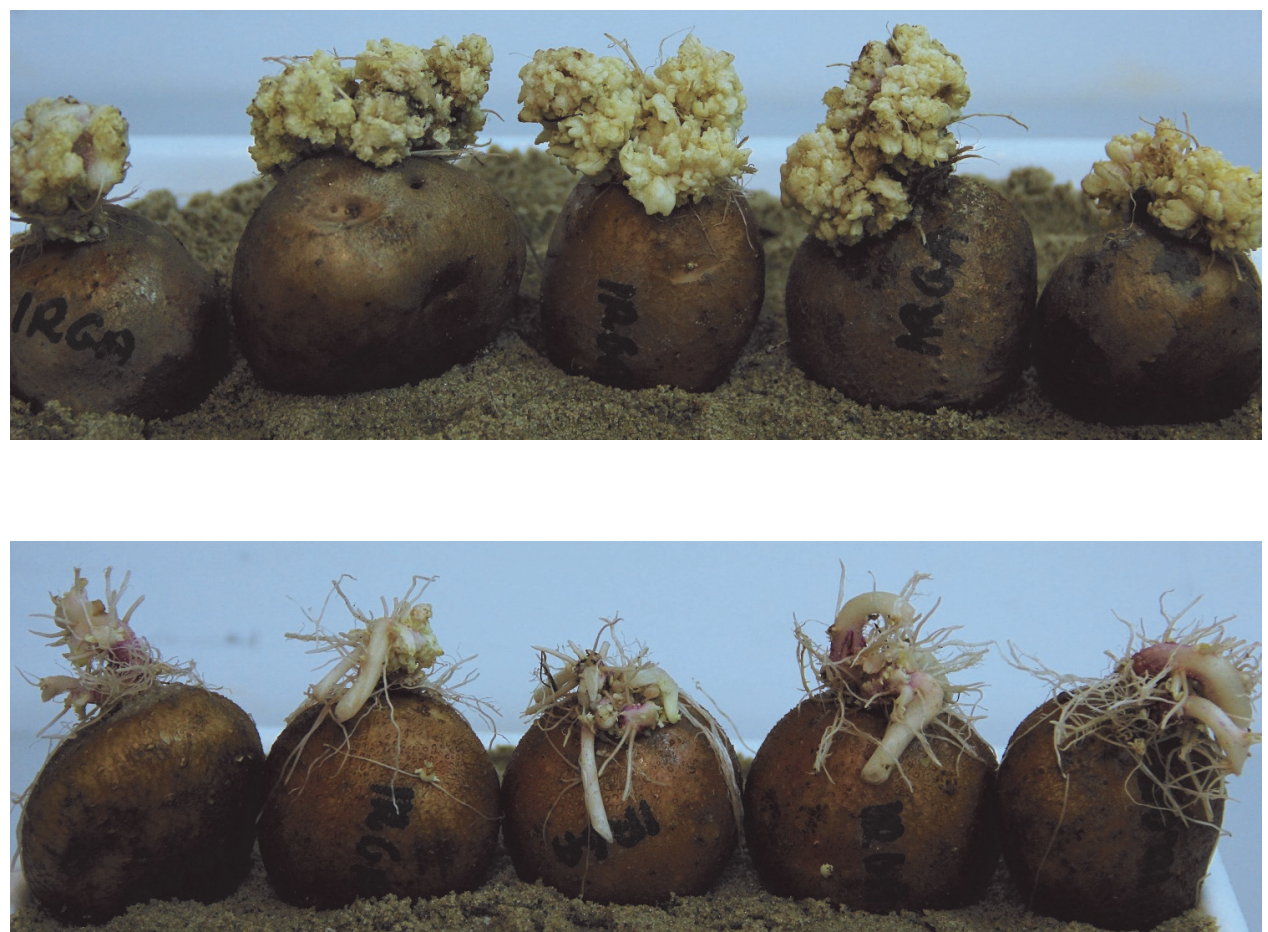

Photo 1. $(+)$ - positive reaction four weeks after inoculation - predominant wart formation.

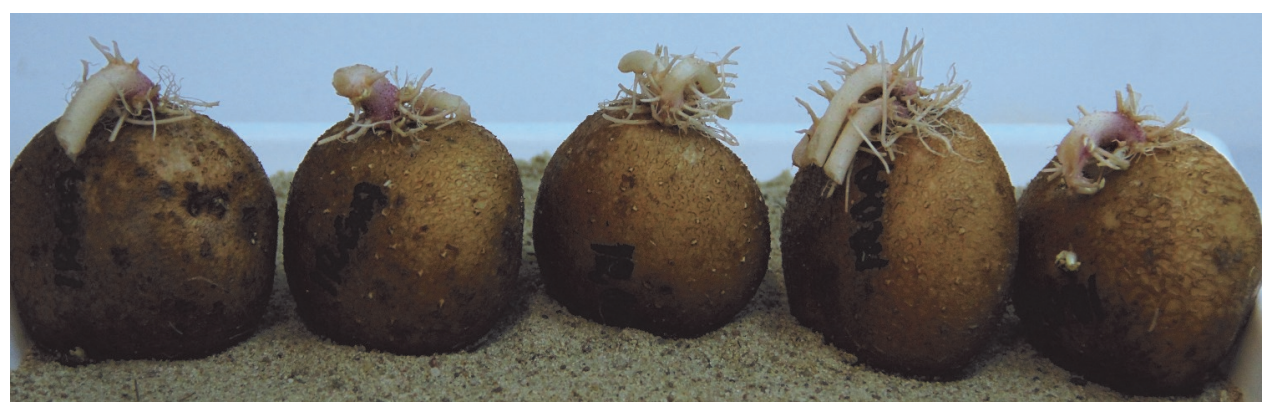

Photo 2. ( \pm ) - intermediate reaction four weeks after inoculation - proliferation of sprouts is visible, but the malformation of shoot is much weaker in comparison to extremely susceptible cultivars.

Photo 3. (-) - negative reaction four weeks after inoculation - no warts.

\section{REFERENCES}

Anonymous. 1996. Synchytrium endobioticum. In Quarantine Pests for Europe, 2nd edn. CAB International, Wallingford (GB). 
Anonymous. 1999. EPPO Standards PM 3/59 Synchytrium endobioticum: soil tests and de-scheduling of previously infested plots. Bull. OEPP/EPPO Bull. 29: 225-231.

Anonymous. 2004. EPPO Standards PM 7/28 Synchytrium endobioticum. Bull. OEPP/EPPO Bull. 34: 213 218.

Baayen R., Cochius G., Hendriks H., Meffert J., Bakker J., Bekker M., van den Boogert P., Stachewicz H., and van Leeuwen G. 2006. History of potato wart disease in Europe-a proposal for harmonisation in defining pathotypes. European J. Plant Pathol. 116:21-23.

Çakir E., van Leeuwen G.C.M., Flath K., Meffert J.P., Janssen W.A.P., and Maden S. 2009. Identification of pathotypes of Synchytrium endobioticum found in infested fields in Turkey. Bull.OEPP/EPPO Bull. 39:175-78.

Flath K., Przetakiewicz J. van Rijswick P.C.J., Ristau V., and van Leeuwen G.C.M. 2014. Interlaboratory tests for resistance to Synchytrium endobioticum in potato by the Glynne-Lemmerzahl method. Bull. OEPP/ EPPO Bull. 44: 510-517.

Hampson M.C. 1993. History, biology and control of potato wart disease in Canada. Canadian J. Plant Pathol. 15: $223-244$

Hooker W.J. ed. 1981. Compendium of Potato Disease. Am. Phytopatol. Society, St. Paul, Minnesota. pp.125

Karling J.S. 1964. Synchytrium, Academic Press. New York and London.

Langerfeld E. and Stachewicz H. 1994. Assessment of varietal reactions to potato wart (Synchytrium endobioticum) in Germany. Bull. OEPP/ EPPO Bull. 24, 793-798.

Obidiegwu J.E., Flath K., and Gebhardt C. 2014. Managing potato wart: a review of present research status and future perspective. Theor. Appl. Genet. 127:763-80.

Przetakiewicz J. 2008. Assessment of the resistance of potato cultivars to Synchytrium endobioticum (Schilb.) Per. in Poland. Bull. OEPP/EPPO Bull. 38: 211-215.

Przetakiewicz J. 2014. Manual of Security Sensitive Microbes and Toxins: Synchytrium endobioticum, ed. Dong Liu, 823-829. Boca Raton, London, New York: CRC Press.

Przetakiewicz J. 2015. First report of new pathotype 39(P1) of Synchytrium endobioticum causing potato wart disease in Poland. Plant Dis. 99: 285.2.

Przetakiewicz J. 2016. A modification of the Potoček's tube test for diagnostic of Synchytrium endobioticum (Schilb.) Perc. a causal agent of potato wart disease. Indian Phytopathol. 69 (4s): 260-265.

Przetakiewicz J., Plich J. 2017. Assessment of potato resistance to Synchytrium endobioticum, Plant Breeding and Seed Science, 76: 37-43

Steinmöller S., Bandte M., Büttner C., Müller P. 2012. Effects of sanitation processes on survival of Synchytrium endobioticum and Globodera rostochiensis. European Journal of Plant Pathol. 133: 753763.

USDA. 2007. Recovery Plan for Potato Wart Disease Caused by Synchytrium endobioticum (Schilbresky) Percival. www.ars.usda.gov/ARSUserFiles/opmp/PotatoWart70109.pdf 